\title{
BIOGEOGRAPHICAL DISTRIBUTION OF THE SOUTH MESOREGION, MARANHÃO, BRAZIL
}

\author{
Yuri Teixeira Amaral ${ }^{1, a,}$; Gustavo Pereira Lima ${ }^{1}$; Carlos Alberto Algarves Peixoto Neto ${ }^{1}$; Mayanna \\ Karlla Lima Costa ${ }^{2}$ and Glécio Machado Siqueira ${ }^{3}$
}

\begin{abstract}
${ }^{1}$ Mestrando no Programa de Pós-Graduação em Biodiversidade e Conservação, Universidade Federal do Maranhão, São Luís, Brazil. 'Doutoranda no Programa de Pós-Graduação BIONORTE, Universidade Federal do Maranhão, São Luís, Brazil. ${ }^{3}$ Professor, Departamento de Geociências, Universidade Federal do Maranhão, São Luís, Brazil. a) Instituto Chico Mendes de Conservação da Biodiversidade.

${ }^{*}$ Corresponding author: yuri.baba@gmail.com
\end{abstract}

\begin{abstract}
The Mesoregion South Maranhense covers the 19 cities located at the extreme south of the Maranhão state and is geographically in three Microregions: The Chapada das Mangabeiras, Gerais de Balsas and Porto Franco. The climate is semi-humid tropical and humid tropical type, in the Chapada das Mangabeiras and Porto Franco respectively. Central Plateau and Chapada of the Parnaíba basin, with elevated areas, and hills occurrences, characterize the relief. This work aimed to characterize the south mesoregion of Maranhão State. The predominant biome is cerrado, with small sized trees and tortuous stems, featuring the several Phyto physiognomy of the biome. In the region predominates the archaeological sites where evidence the colonization of the region by nomadic peoples who lived by hunting, fisheries, and subsistence agriculture. In economic terms, the region has vast fields of extensive cattle and the presence of agribusiness. In relation to the occupation by demography, the South does not present urban agglomerations, the population density is of 4.2 inhabitants $/ \mathrm{km}^{2}$. The main conservations units of the region are: Chapada das Mesas National Park and Parnaíba Headwater River National Park both seeking the protection of the natural resources, of the cerrado biome fauna and flora.
\end{abstract}

Key words: Maranhense South, biogeographical aspects, Maranhão.

\section{DISTRIBUIIÇÃO BIOGEOGRÁFICA DA MESORREGIÃO SUL, MARANHÃO, BRASIL}

RESUMO: A Mesorregião Sul Maranhense abrange os 19 municípios situados ao extremo sul do Estado do Maranhão e geograficamente está em três Microrregiões: Chapada das Mangabeiras, Gerais de Balsas e Porto Franco. O clima da região é do tipo tropical semi-úmido e tropical úmido, na Chapada das Mangabeiras e Porto Franco respectivamente. 0 relevo se caracteriza por Planalto Central e Chapada da bacia do Parnaíba, com áreas elevadas, e ocorrências de serras. Objetivou neste trabalho caracterizar a mesorregião sul do Estado do Maranhão. O bioma predominante é o cerrado, com árvores de porte baixo e caules tortuosos, caracterizando as diversas fitofisionomias do bioma. Na região predomina os sítios arqueológicos onde evidenciam a colonização da região, por povos nômades, que viviam da caça, pesca e da agricultura de subsistência. Em termos econômicos, a região possui vastos campos de pecuária extensiva, e a presença do agronegócio. Com relação a ocupação por demografia, o Sul não apresenta aglomerados urbanos, a densidade populacional é de 4,2 habitantes/km2. As principais unidades de conservação da região são: Parque Nacional da Chapada das Mesas e Parque Nacional das Nascentes do Rio Parnaíba ambas visam a proteção dos recursos naturais, fauna e flora do bioma cerrado.

Palavras-chave: Sul maranhense, Aspectos biogeográficos, Maranhão.

Received: Aug. 10, 2016 - Accepted: Nov. 23, 2016

\section{INTRODUCTION}

The Maranhense South Mesoregion covers the 19 cities in the extreme south of the Maranhão state and is divided into three Microregions: Chapada das Mangabeiras, Gerais de Balsas and Porto Franco. With great agricultural vocation, the region had a fast development in the last 30 years; however, the advance of the agricultural frontier is given on the Cerrado biome, considered a Hot Spot for global biodiversity. Located in the state threefold frontier with Tocantins and Piaui boundary are partially defined by the gutters of Tocantins and Parnaíba Rivers, respectively. As a result, the mesoregion is 
located in the Maranhão Basin portion of these two important rivers. Figures 1 show the location of the Maranhense South Mesoregion, the Microregions, both produced in QGIS 1.8 with data from the Ministry of Environment (MMA, 20161).
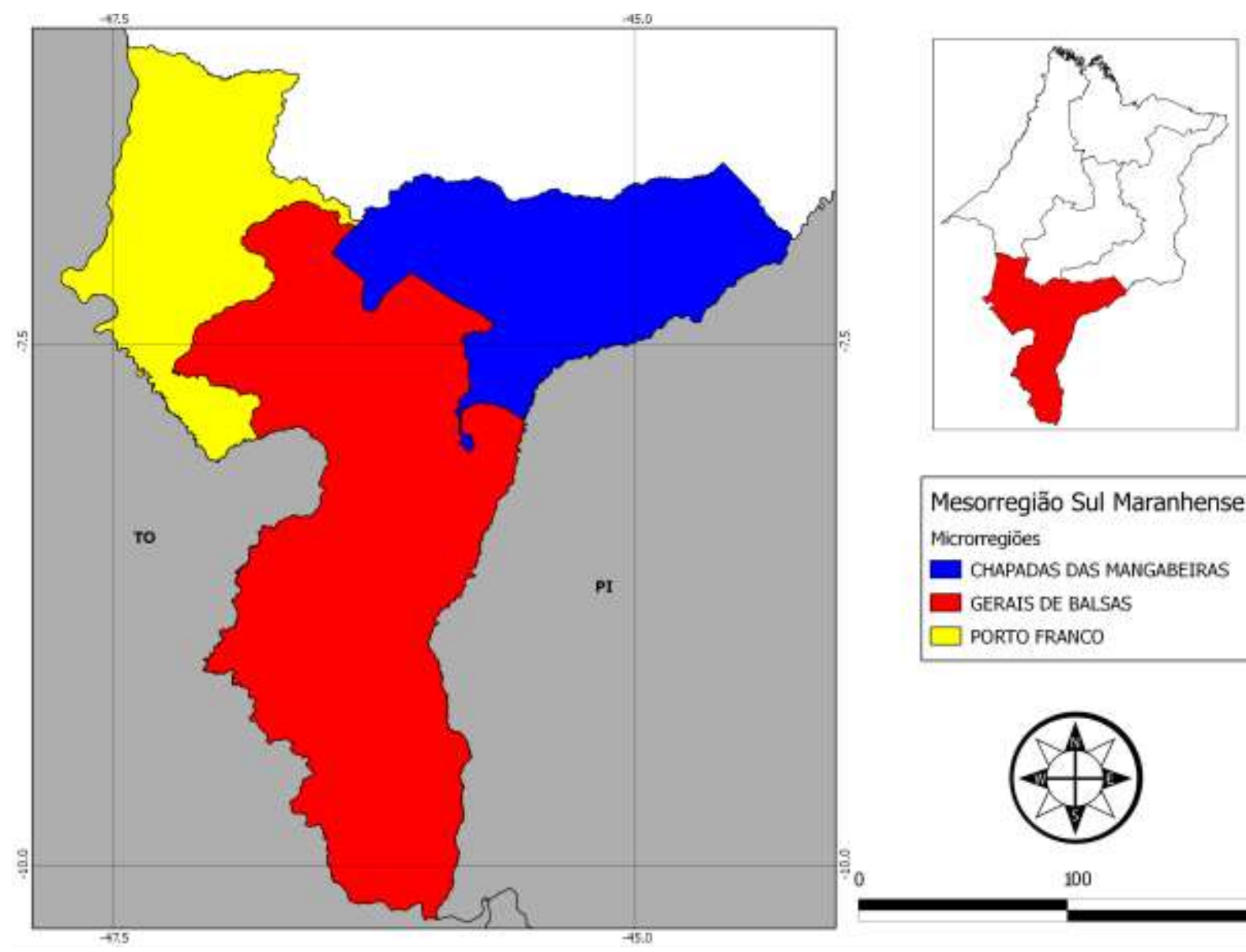

Mesorregião Sul Maranhense Microrregiōes

- CHAPADAS DAS MANGABEIRAS GERAIS DE BALSAS PORTO FRANCO

Figure 1. Maranhense South Mesoregion location map (MMA, 2016).

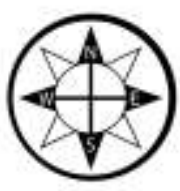

100

Geologically the Maranhense South Mesoregion is formed by sedimentary rocks of the Parnaíba and San Franciscans Basins. The lithotypes that comprises the Parnaiba basin were deposited in the Paleozoic era, during the junction of the great continent Pangea and formed the Balsas Group, which is composed of rocks of Piaui formations (sandstones, with intercalation of siltstones and mudstones, and leaflets containing lenticular intercalations of marine origin of limestone), Fire Stone (siltstones and leaflets, limestones and silexitos) Horsefly (siltstones, sandstones, leaflets) and Sambaíba reddish and whitish sandstones), which outcrop throughout the south of Maranhão. In the Sanfranciscana Basin outcrop rocks of Urucuia Group, consisting of sandstones of eolian dunes and interlaced river, as well as mudstones and conglomerates of alluvial plain (Nascimento, 2013).

The relief is formed by the plateau and Chapada of the Parnaíba Basin, constituting the north end of the Central Plateau. The Chapada das Mangabeiras is the south end 
elevation and makes the natural boundary between Maranhão and Tocantins, where the rivers Manuel Alves Grande, and the tributaries of the Parnaíba and Balsas Rivers are born. It still occurs in the Fortaleza dos Nogueiras and Serra Vermelha Hills. The landscape is dominated by chapadões, Chapada, boards and cuestas of higher resistance to erosion, being the higher altitudes, which decrease gradually towards to the north (Rios,2001).

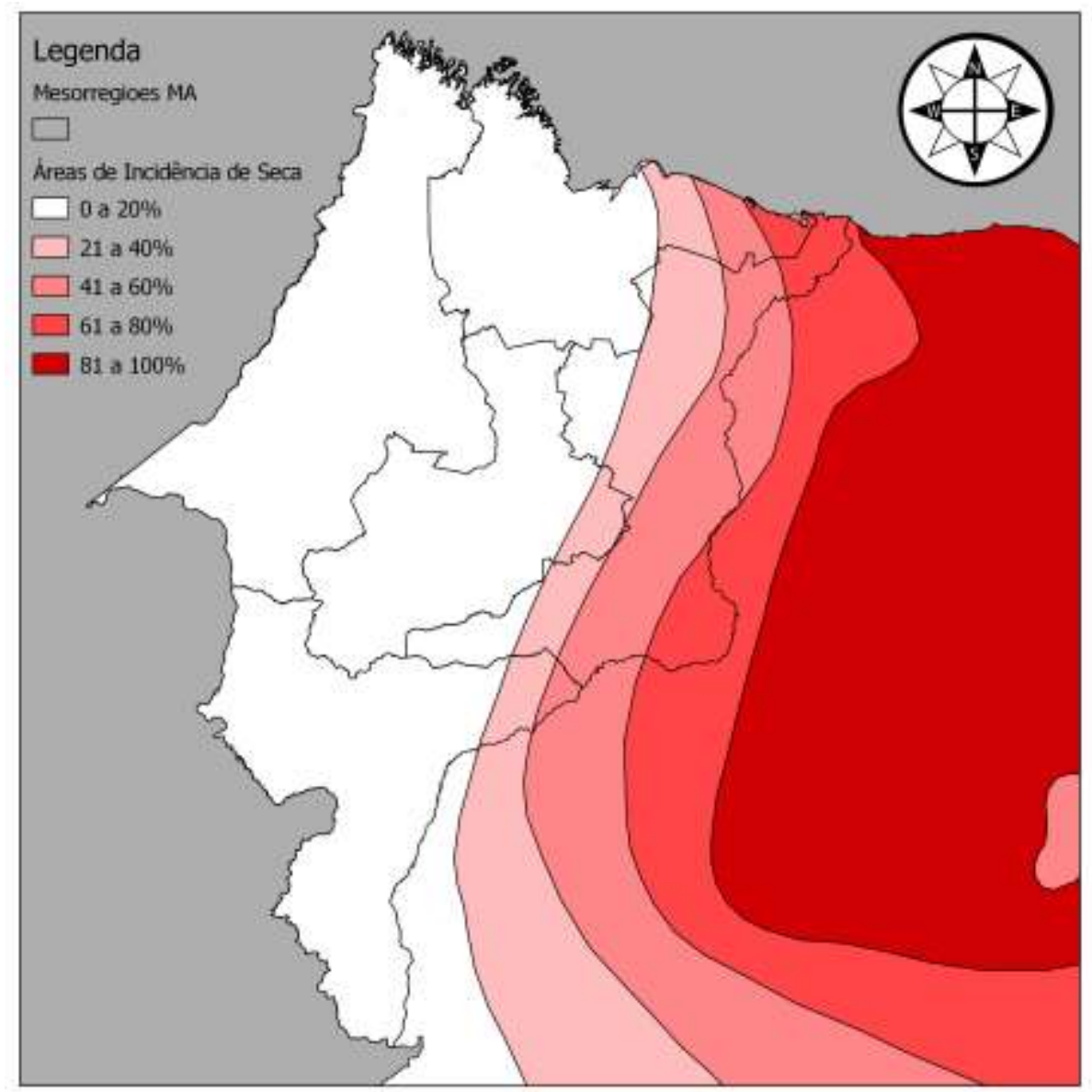

Figure 2. Dry Incidence Area in the northeastern semi-arid according to MMA (2016).

In the Maranhense south occurs two types of climates: semi-moist tropical, in the microregions of Chapada das Mangabeiras and Gerais de Balsas, and the Tropical Moist climate in Porto Franco. The temperature is high the whole year and occurs two characteristics seasons throughout the year, a dry and a rainy season. The semi-moist tropical climate is under influenced of the semi-arid backlands, presenting lower rate of rains, already the moist equatorial climate presents a greater rainfall (Rios, 2001). According to the geoprocessing data MMA (2016), the Maranhense south is not inserted into subject to desertification area, but the northeast of the microregion of the Chapada das Mangabeiras has areas with 20 to $40 \%$ of Dry Incidence (Figure 2).

The region is found in the Cerrado, in the south Maranhense, due to the drier climate, it presents in low size and sparse trees, being overcome by the herbaceous stratum, known 
as Cerradinho Fields. The Chapadões occur in an intermediate strip between the Cerrados region and the plateau. With an altitude of 200 to 300 meters, its landscape varies with the presence of low and fertile valleys which interconnect to the Chapada of varied heights (Rios, 2001; Nascimento, 2013).

Archaeological sites show that prehistoric people occupied the region for over 10 million years organizing in semi-nomadic communities, practicing hunting, fishing and subsistence agriculture. However, the colonization and integration of the south of the state to the colonial socioeconomics was given only in the early nineteenth century, when the region was occupied for the development of extensive livestock. At the time, indigenous groups inhabited the region but were decimated along the colonization process (De Castro, 2010). Currently the agriculture has dominated the local economy, being that the soil degradation in some farms is already notorious and have demanded conservation measures in some farms, even though the producers adopt environmental management in its processes (Costa et al., 2010; Rodrigues and Alencar, 2011).

The land occupation for agribusiness has displaced some traditional populations, which sell their original lands in the Chapada, more conducive to the monoculture and mechanization, and become to occupy the valley areas, where they exert family subsistence agriculture. This displacement has two consequences: the suppression of the cerrado in the Chapada for conversion of land use, and a pressure increase on ecosystems located in valleys. There are impacts reports on the archaeological heritage too, mainly by the intensification of cattle breeding that tramples on the sites and destroys rock paintings to scratch in the walls of the caves that served as a shelter to the primitive human being (De Castro, 2010).

The Maranhense south presents the lowest demographic of the State. Currently, 281,692 people inhabit the region, which has $67607 \mathrm{~km}^{2}$, totaling a population density of 4.2 inhabitants $/ \mathrm{km}^{2}$. According to IBGE (2016), there are no major urban agglomerates in the Maranhense south.

There are no demarcated indigenous lands in the Maranhense South, which may be related to the genocide practiced by the settlers. Only two conservation units have been created in the region, the National Park of Chapada das Mesas (NPCM) and Headwaters of the Parnaíba River (NPHPR). Although there are few Conservation Units, they have an important role in biodiversity conservation in the region. The NPHPR preserves cerrado samples in semi-moist tropical climate and NPCM in moist tropical climate. Both parks houses headwater and contribute to the supply of the Tocantins, Parnaíba and others Rivers (MMA, 20161).

- National Park of Chapada das Mesas With 159,952 hectares, the NPCM was established on December 12, 2005, by the federal government, aiming to protect samples still untouched of the Maranhense cerrado, promote the sustainable development of the region through tourism and promote scientific research. Although predominate the cerrado vegetation strict sensu, there is also cerradões, dirty fields, clean fields, paths and buriti groves in a smaller proportion. There are about 400 headwaters in the NPCM, which contribute to the supply of Farinha river to the north and Itapecuru river to the south. The conservation 
unit has not yet been regularization object, develop traditional activities in the area. being that the until today the inhabitants
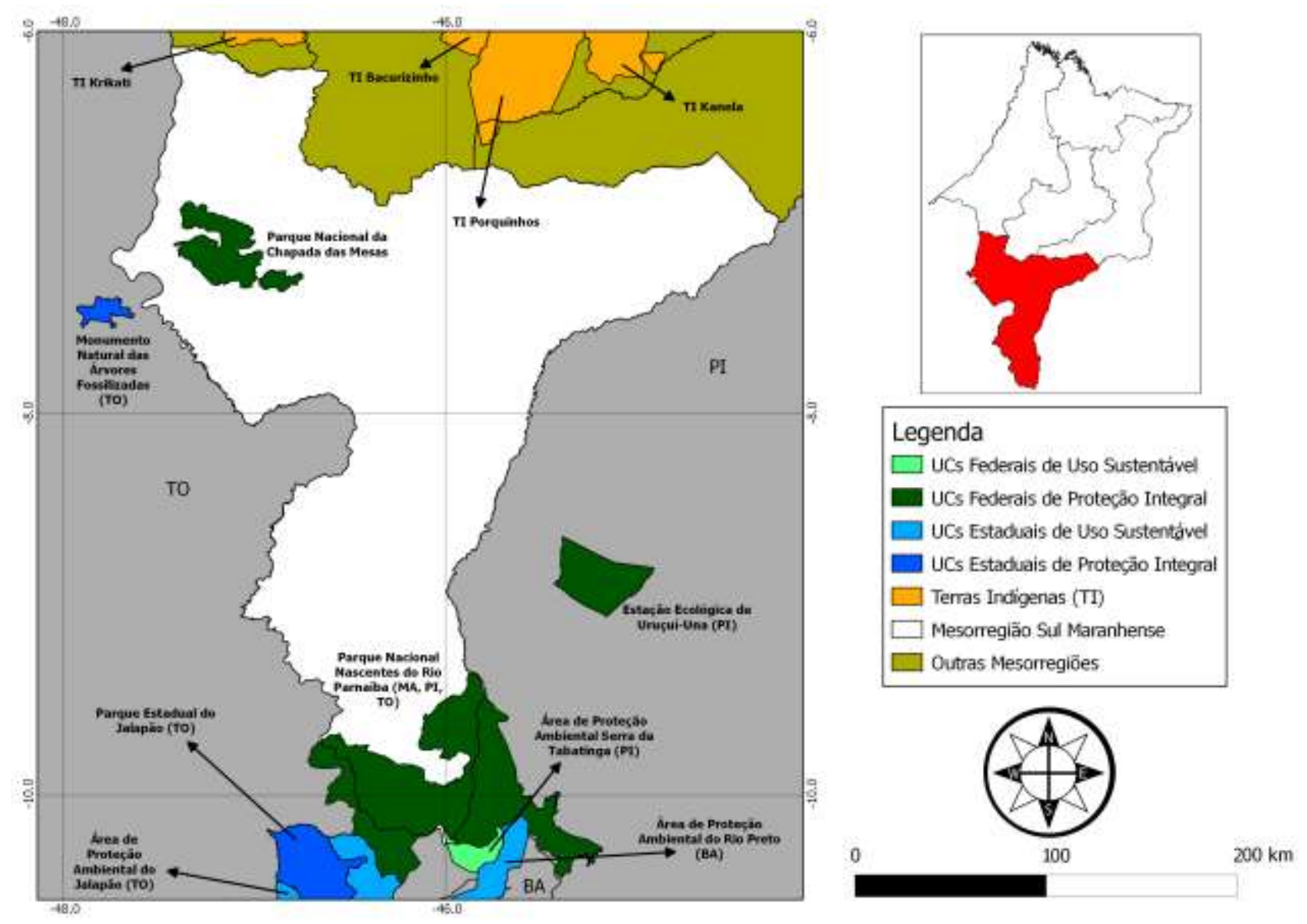

Figure 3. Conservation units of the Maranhão State (Brazil, MMA, 2016).

- National Park of the Headwaters of the Parnaíba River - has 724,325 hectares and dated 16 July 2002. The park houses several kinds of cerrado vegetation, such as chapadões, field-cerrado, clean fields and buriti groves. Its waters supply the Parnaiba River Basin, as the name suggests, housing several headwaters. Jaguar (Panthera onca), Giant-armadillo (Priodontes maximus), Green's puma (Puma concolor greeni) are some endangered species found in the area. The park lands were not misappropriated and there is a human presence in the protected area.
The Ecological-Economic Zoning (EEZ) calls attention to a number of classified areas as needing recovery and fragile. Figure 3 presents a map of the EEZ and the location of the two parks, showing that sensitive areas are unprotected, and there are many areas requiring recovery.

\section{FINAL CONSIDERATIONS}


The Maranhense South is an important region from Maranhão State, with economic aspects that greatly contributes to the country's economy. However, it is a region that is very degraded by the inadequate use. It houses important historical information that must be preserved to better explain the colonization of the state process.

\section{REFERENCES}

Costa, K.S.P.; Sousa, C.J.; Silva, M.B. 2010. Estudo da Degradação dos Solos pela Exploração Agrícola na Fazenda Pé-de-Bicho no Município de Balsas-MA. In: Abordagens Geográficas da Multiplicidade dos Espaços Maranhenses. [s.I.] Editora UEMA, 2010. p. 252-262.

Castro, C.E. 2010. Vales e Chapadas, Conflitos Socioambientais e Arqueológicos no Sul do Maranhão. In: Abordagens Geográficas da multiplicidade dos Espaços Maranhenses. [s.I.] Editora UEMA, 2010. p. 8-25.

IBGE, 2016: http://www.ibge.gov.br/home/estatistica, acessado em 24/09/2016.

ICMBio, 20161: http://www.icmbio.gov.br/portal/unidadesde conservacao/biomasbrasileiros/cerrado/unidades-de-conservacaocerrado/2079-parna-da-chapada-das-mesas, acessado em 24/09/2016.

ICMBio,20162:

http://www.icmbio.gov.br/portal/unidadesde conservacao/biomasbrasileiros/cerrado/unidades-de-conservacaocerrado/2100-parna-nascentes-do-rioparnaiba, acessado em 24/09/2016.

MMA, 2016a: http://mapas.mma.gov.br/i3geo/datadownloa d.htm, acessado em 24/09/2016.
MMA, 2016b: http://sistemas.mma.gov.br/cnuc/index.php?i do=relatorioparametrizado.exibeRelatorio\&re latorioPadrao=true\&idUc=272, acessado em 24/09/2016

MMA, 2016c: http://sistemas.mma.gov.br/cnuc/index.php?i do=relatorioparametrizado.exibeRelatorio\&re latorioPadrao=true\&idUc=156, acessado em 24/09/2016

Nascimento, I.C. 2013. Geodiversidade do estado do Maranhão. Teresina/PI: CPRM.

Rios, L. 2005. Estudos de Geografia do Maranhão.

RODRIGUES, S.J.D.; ALENCAR, F.A.G. 2011. Considerações sobre a apropriação do espaço maranhense pelo agronegócio da soja: a ideologia do desenvolvimento e a acumulação de terras na microrregião dos gerais de balsas. Boletim Goiano de Geografia, v. 31, n. 1, p. 27-40. 